\title{
Intraventricular bone dust migration after neuroendoscopy: report of 2 cases
}

\author{
Tarek Y. El Ahmadieh, MD, ${ }^{1}$ Cody B. Wolfe, BS, ${ }^{2}$ Joyce Koueik, MD, ${ }^{3}$ Bradley E. Weprin, MD, ${ }^{1}$ \\ Bermans J. Iskandar, MD, ${ }^{3}$ and Angela V. Price, MD ${ }^{1}$

\begin{abstract}
1Department of Neurological Surgery, Children's Medical Center, The University of Texas Southwestern, Dallas; '2Department of Neurological Surgery, School of Medicine, The University of Texas Southwestern, Dallas, Texas; and ${ }^{3}$ Department of Neurological Surgery, American Family Children's Hospital, The University of Wisconsin School of Medicine and Public Health, Madison, Wisconsin
\end{abstract}

\begin{abstract}
Neuroendoscopy has demonstrated safety and efficacy in the treatment of a host of pediatric neurosurgical pathologies. With the increase in its applicability, several associated complications have been described in the literature. A common practice in pediatric neurosurgery is the use of Gelfoam sponge pledget in the burr hole, followed by bone fragments and dust (obtained from the created burr hole), to cover the dural defect. This technique is used to enhance burr hole sealing and potentially prevent CSF leakage from the surgical site. Reports on intracranial bone dust migration associated with this technique are scarce. The authors report 2 cases of intracranial migration of bone fragments after an endoscopic third ventriculostomy and an endoscopic colloid cyst resection. The bone fragment migration was thought to be caused by negative pressure from a lumbar puncture in one case and external trauma to the head in the other. As endoscopy becomes more widely used, it is important to be aware of this potential complication that may in some cases require an intervention. A review of the cases reported in the literature is provided and a technique is suggested to help prevent this complication.
\end{abstract}

https://thejns.org/doi/abs/10.3171/2018.5.PEDS18152

KEYWORDS neuroendoscopy; bone dust migration; hydrocephalus; endoscopic third ventriculostomy; endoscopy; surgical technique

$\mathrm{N}$ EUROENDOSCOPY is an established and important tool in the armamentarium of the modern neurosurgeon. ${ }^{3,4}$ The indications for its use continue to grow, and the endoscope is currently used as a standalone device to treat hydrocephalus, ${ }^{10}$ obtain a biopsy or resect a tumor ${ }^{11,14}$ fenestrate or resect an intraventricular cyst, ${ }^{6}$ or evacuate intraventricular hemorrhage..$^{13}$ It is also used as a complementary tool with microneurosurgery. $1,7,12,15,17$ Endoscopic third ventriculostomy (ETV), intraventricular cyst resection, and intraventricular tumor biopsy are a few of the more commonly performed procedures in the pediatric population. A common practice in pediatric neurosurgery is the use of Gelfoam sponge pledget followed by bone fragments and dust (obtained from the burr hole) to cover the dural defect. ${ }^{916}$ Reports on intracranial migration of bone fragments and dust are scarce. ${ }^{8,16,18}$ We report 2 cases of intracranial migration of bone fragments after an ETV and an endoscopic colloid cyst resection. As endoscopy becomes more widely used, it is important to be aware of this potential complication. A technique is also suggested to help prevent this complication.

\section{Case Reports}

Case 1

This 13-year-old female patient with a history of seizures and a tectal glioma was diagnosed in March of 2017 with associated hydrocephalus (Fig. 1A). The patient was 

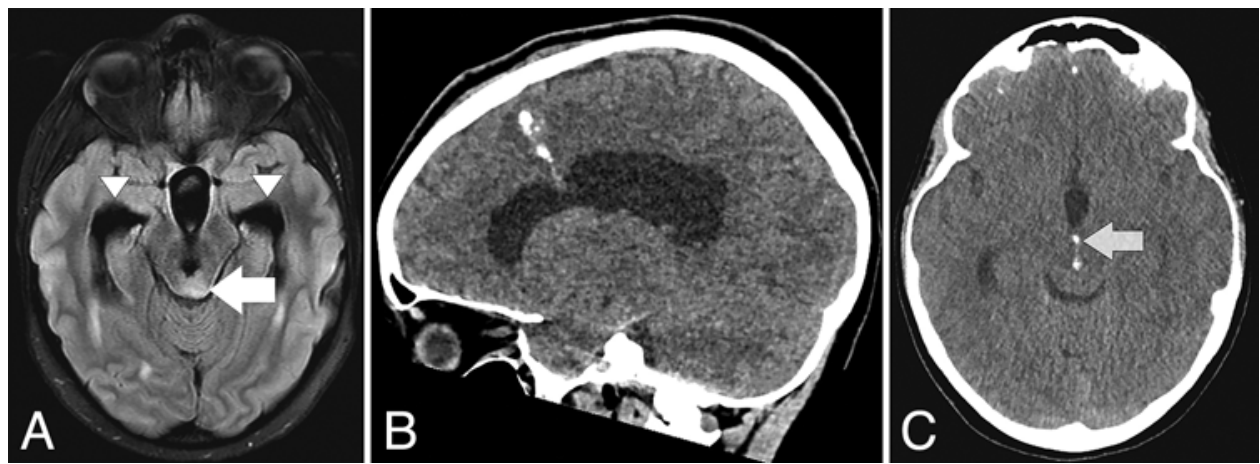

FIG. 1. Case 1. A: T2-weighted FLAIR MR image of the brain demonstrating a tectal glioma (white arrow) and secondary hydrocephalus (enlarged temporal horns, white arrowheads). B and C: Sagittal (B) and axial (C) images from CT scan performed the day after admission showing migration of Gelfoam and bone fragments into the endoscopy tract after lumbar puncture (B) and bone dust migration into the third ventricle (white arrow, C).

admitted to the hospital and received an ETV through a right frontal burr hole. The procedure was uneventful. A piece of Gelfoam was inserted in the endoscopy tract after the endoscope and peel-away sheath were removed. The dural defect was covered with bone fragments and dust that were obtained from the burr hole. The patient was discharged on the next day in stable condition. Later, on the same day, she was brought back to the emergency room with high-grade fever, neck pain, and headache. A brain CT scan showed decreased third and fourth ventricle size as compared to previous scans, with no other pathology. There was high suspicion for meningitis. Thus, the patient received a lumbar puncture $(2$ tubes $=16 \mathrm{ml})$ and was started on empirical antibiotics and steroids. On day 1 after admission, she underwent another brain CT scan because of persistent headaches and vomiting. The repeat CT scan showed migration of the Gelfoam and bone fragments into the endoscopy tract and into the third ventricle (Fig. 1B and C). The ventricles remained small in size. The patient received corticosteroids and empirical antibiotics for approximately 5 days until the final CSF cultures showed no organism growth, leading to a diagnosis of aseptic meningitis. Her headaches gradually improved
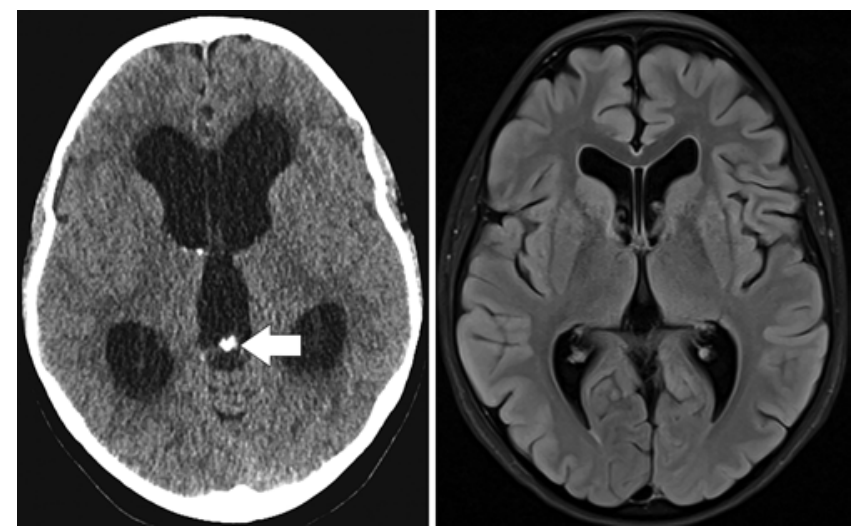

FIG. 2. Case 1. Left: Axial CT image showing recurrent hydrocephalus with enlarged ventricles and stable bone fragments in the third ventricle (white arrow). Right: Axial T1-weighted MR image obtained at 4-month follow-up demonstrating decreased ventricle size. and she ambulated and tolerated food intake. She was discharged on hospital day 6 on a steroid taper.

Four months after discharge, the patient re-presented to the emergency room with progressive headaches, which had started approximately 3 months earlier (i.e., 1 month after discharge). A brain CT scan showed enlarged third and fourth ventricles with stable bone fragments in the third ventricle and endoscopy tract (Fig. 2 left). Given the severity of her headaches, worsening blurry vision, and inability to lie flat, the patient was deemed too ill to undergo brain MRI. The decision was made to directly proceed with a repeat ETV with the possibility of a ventriculoperitoneal shunt placement. The lateral ventricle was accessed via a left frontal burr hole. The floor of the left lateral ventricle and anterior third ventricle were found to be studded with bone dust and small bone fragments. The ETV opening appeared to have healed with a thin and translucent membrane that was also studded with bone dust. The membrane was perforated with a 3-Fr mini-compression balloon catheter, and the new hole was enlarged with balloon inflation. The patient tolerated the procedure well, and her symptoms gradually improved. She was discharged home on postoperative day 2 . She was seen in clinic for follow-up and was found to be doing well neurologically. A 4-month follow-up brain MRI examination showed decreased ventricle size and preservation of flow across the third ventriculostomy defect (Fig. 2 right). As of the 6-month follow-up visit, she was continuing to do well.

\section{Case 2}

This 26-year-old female patient had a history of a third ventricular colloid cyst diagnosed during workup for headaches (Fig. 3A). At the time of presentation, she was complaining of daily headaches that had increased in frequency over a period of 2 years. The headaches were associated with dizziness and blurry vision. The results of fundoscopy and neurological examinations were normal. Brain MRI showed a stable colloid cyst in the superior/ anterior third ventricle in an interforniceal location with no evidence of hydrocephalus. She underwent complete endoscopic resection of the colloid cyst via a right frontal burr hole. An external ventricular drain was placed, and 


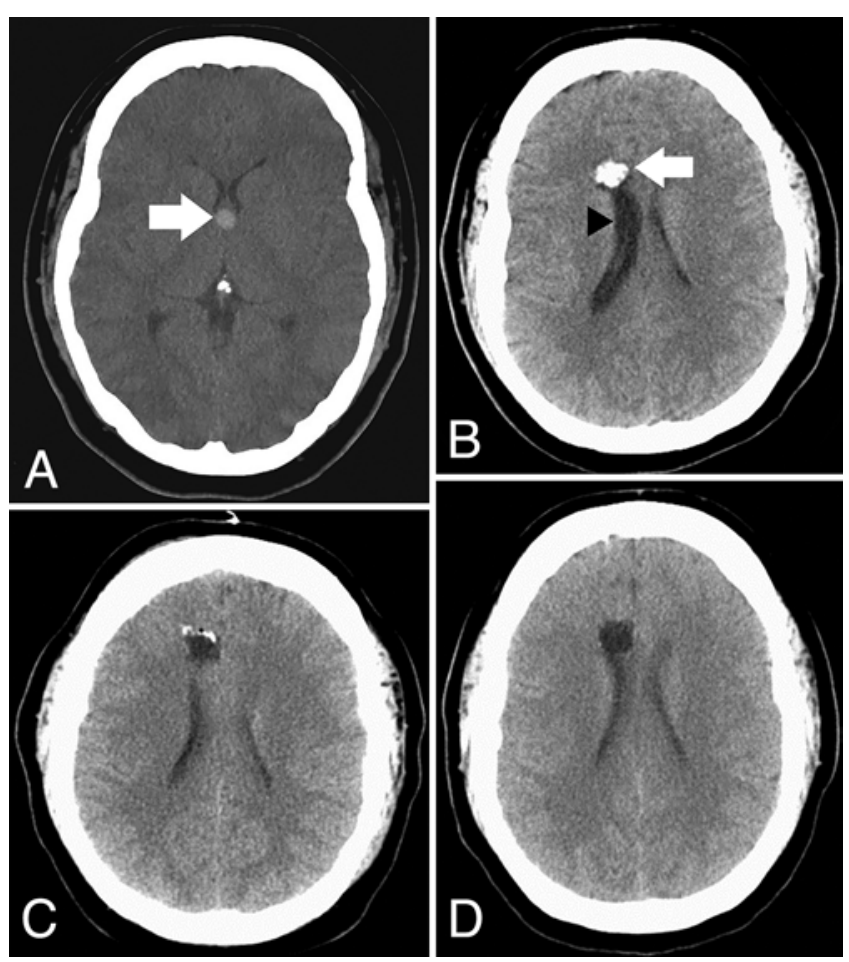

FIG. 3. Case 2. A: Axial CT image showing a colloid cyst in the third ventricle with no evidence of hydrocephalus (white arrow). B: Axial CT image obtained 3 days after the patient was struck on the head, 10 weeks postoperatively, showing migrated bone dust along the endoscopy tract after head trauma (white arrow) and asymmetrical dilation of the right ventricle (black arrowhead). C: Postoperative axial CT image showing interval decrease in the size of the right ventricle with near resolution of the calcifications along the endoscopy tract. D: Axial CT image obtained at 3-year follow-up showing stable ventricle size and no evidence of bone growth.

the dural defect was covered with Gelfoam followed by the bone fragments and dust created by the burr hole. The drain was removed on postoperative day 1 , and she was discharged home on postoperative day 3 with no complications.

She had local incisional problems from "scratching" that were treated with sutures and intravenous antibiotics. Ten weeks postoperatively, she was struck on her head while wrestling with a cousin. She presented 3 days later with dull throbbing pain in the right temporal region, associated with nausea and vomiting, and a temperature of $38.3^{\circ} \mathrm{C}$. A head CT scan showed asymmetrical right ventricular dilation with dystrophic calcification along the previous ventriculostomy tract (Fig. 3B). She was taken to the operating room for an endoscopic re-exploration, which revealed displacement of the Gelfoam and bone fragments into the endoscopy tract, approximately 3-4 $\mathrm{cm}$ deep. These were removed endoscopically. In the right lateral ventricle, punctate material was observed along the ependyma, and the right interventricular foramen was occluded by inflammatory membranes. The septum pellucidum was fenestrated to allow visualization of the contralateral ventricle and interventricular foramen, both of which appeared normal. The skin was closed over the burr hole site. A head CT scan obtained on postoperative day 1 showed interval decrease of the size of the right ventricle with near resolution of the calcifications along the tract (Fig. 3C). The patient had no postoperative complications and had stable imaging findings 3 years postoperatively (Fig. 3D).

\section{Discussion}

Neuroendoscopy has demonstrated safety and efficacy in the treatment of a host of neurosurgical pathologies. $1,3,4,6,7,10-15,17$ With the increase in its applicability, a multitude of complications have been described in the literature, including intracranial bleeding, technique failure or recurrence of the pathology (e.g., hydrocephalus or intraventricular cyst), inconclusive biopsy, CSF leak, new neurological deficit, seizure, hyponatremia, meningitis, pseudomeningocele, ophthalmoplegia, diabetes insipidus, and cardiac arrhythmias., ${ }^{2,10}$ Less commonly described, however, is the intracranial bone migration complication associated with using bone fragments and dust in the closure of burr holes. This is a commonly used technique, particularly in pediatric neurosurgery, to enhance burr hole sealing and potentially prevent CSF leakage from the surgical site. A Gelfoam sponge is typically inserted into the endoscopy tract to help prevent the migration of bone fragments into the ventricular system and to further prevent CSF leak. While this technique is effective and safe in most of cases, reports of complications arising after migration of bone fragments and dust have emerged. ${ }^{5,8,16,18} \mathrm{In}$ searching the literature, we found 5 cases of such complications, and 2 additional cases from 2 centers are presented in this report. A summary of all of these cases, including clinical and radiographic presentations and outcomes, is provided in Table 1.

The intracranial migration of bone fragments can obstruct CSF outflow tracts, causing hydrocephalus. Among the cases reported in the literature, 3 patients re-presented with worsening headaches and recurrent hydrocephalus that was deemed to be related to bone fragment migration into the ventricles and CSF outflow obstruction. ${ }^{8,16,18}$ In all 3 cases, the patients were taken to the operating room for endoscopic removal of the bone fragments; complete resolution of symptoms was reported in 2 cases, and no outcome data were reported in the third. One of the 3 patients had undergone a lumbar puncture for aseptic meningitis prior to this complication, which theoretically may have contributed to bone fragment migration via a negative pressure mechanism. In case 1 of the present report, the patient presented with recurrent hydrocephalus 3 months after her initial ETV. The ventricles were found to be studded with bone dust and small bone fragments. However, intraoperatively, it was not thought that a mechanical obstruction was caused by the bone fragments per se. Whether the extensive ventricular bone dust had induced an inflammatory response and membrane formation over the ependyma, and thus contributed to the closure of the stoma, remains hard to prove. In case 2 of the present report, the patient presented 10 weeks after colloid cyst removal with symptomatic, asymmetrical ventricular dilatation (or hydrocephalus). The bone fragment displacement in this case was thought to be related to head 
TABLE 1. Summary of reported cases of bone dust migration after endoscopic procedures

\begin{tabular}{|c|c|c|c|c|c|c|c|c|}
\hline $\begin{array}{l}\text { Authors } \\
\& \text { Year }\end{array}$ & $\begin{array}{l}\text { No. of } \\
\text { Cases }\end{array}$ & Indication* & $\begin{array}{l}\text { Loc of Bone } \\
\text { Dust Migr }\end{array}$ & Clin Course & Radiogr Course & Management & $\begin{array}{c}\text { Clin } \\
\text { Outcome }\end{array}$ & $\begin{array}{l}\text { Radiogr } \\
\text { Outcome }\end{array}$ \\
\hline \multirow[t]{3}{*}{$\begin{array}{l}\text { Thomson } \\
\text { et al., } \\
2003\end{array}$} & \multirow[t]{3}{*}{3} & $\begin{array}{l}\text { Atresia of It } \\
\text { MF }\end{array}$ & $\begin{array}{l}\text { Lt frontal \& occip } \\
\text { horns of lat } \\
\text { ventricle }\end{array}$ & $\begin{array}{l}2 \text { readmissions } \\
\quad \text { for } \mathrm{HA}\end{array}$ & $\begin{array}{l}\text { Postop CT: resol of ventric } \\
\text { dilation }\end{array}$ & $\begin{array}{l}\text { No interven- } \\
\text { tion }\end{array}$ & $\begin{array}{l}\text { ICP normal- } \\
\text { ization \& } \\
\text { Sx resol }\end{array}$ & $\begin{array}{l}\text { Enlarging } \\
\text { radiopacities } \\
\text { seen w/ each } \\
\text { subsequent } \\
\text { CT scan }\end{array}$ \\
\hline & & $\begin{array}{c}\text { Aqueductal } \\
\text { stenosis }\end{array}$ & $\begin{array}{l}\text { Rt frontal horn, } \\
\text { rt occip horn, } \\
\text { \& endoscope } \\
\text { tract }\end{array}$ & No clin Cx & $\begin{array}{l}\text { Postop CT: resol of ventric } \\
\text { dilation }\end{array}$ & $\begin{array}{l}\text { No interven- } \\
\quad \text { tion }\end{array}$ & $\begin{array}{l}\text { Residual } \\
\text { HA, resol } \\
\text { of incont } \\
\text { \& gait dis- } \\
\text { turbance }\end{array}$ & $\begin{array}{l}\text { Stable radi- } \\
\text { opacities } \\
\text { observed at } \\
\text { 3- \& 9-mo } \\
\text { FU CT scans }\end{array}$ \\
\hline & & Pineal tumor & $\begin{array}{l}\text { Floor of 3rd } \\
\text { ventricle \& } \\
\text { ventriculos- } \\
\text { tomy stoma }\end{array}$ & $\begin{array}{l}\text { HAs \& papille- } \\
\text { dema }\end{array}$ & $\begin{array}{l}\text { Postop CT: small calcified } \\
\text { lesion in floor of 3rd } \\
\text { ventricle; FU CT at } 5 \\
\text { wks: progr of calcifica- } \\
\text { tion \& recurrence of HC }\end{array}$ & $\begin{array}{l}\text { Reop to re- } \\
\text { move bone } \\
\text { frags }\end{array}$ & None listed & None listed \\
\hline $\begin{array}{l}\text { Kafadar et } \\
\text { al., } 2010\end{array}$ & 1 & $\begin{array}{l}\text { Cavum ver- } \\
\text { gae cyst } \\
\text { at septum } \\
\text { pellucidum }\end{array}$ & $\begin{array}{l}\text { Endoscopic } \\
\text { tract \& filling } \\
\text { ventricle, ob- } \\
\text { structing MF }\end{array}$ & $\begin{array}{l}\text { Worsening HA } \\
\text { \& vomiting; } \\
\text { LP for aseptic } \\
\text { meningitis }\end{array}$ & $\begin{array}{l}\text { Postop CT: regr of cyst w/ } \\
\text { no other path findings; } \\
\text { FU CT: hyper-dense } \\
\text { bone particles occlud- } \\
\text { ing MF }\end{array}$ & $\begin{array}{l}\text { Reop to re- } \\
\text { move bone } \\
\text { frags }\end{array}$ & $\begin{array}{l}\text { Compl resol } \\
\text { of Sx }\end{array}$ & $\begin{array}{l}\text { Normalization } \\
\text { of ventricle } \\
\text { size w/ decr'd } \\
\text { cyst size }\end{array}$ \\
\hline $\begin{array}{l}\text { Turhan \& } \\
\text { Ersahin, } \\
2011\end{array}$ & 1 & $\begin{array}{l}\text { Mass in } \\
\text { tectum } \\
\text { occluding } \\
\text { aqueduct } \\
\text { of Sylvius }\end{array}$ & $\begin{array}{l}\text { Stoma of tuber } \\
\text { cinereum, in- } \\
\text { fundib recess, } \\
\text { w/in MB, rt lat } \\
\text { wall, dispersed } \\
\text { w/in ventricle }\end{array}$ & $\begin{array}{l}\text { 1-yr FU: pro- } \\
\text { gressive HA } \\
\text { \& diplopia }\end{array}$ & $\begin{array}{l}\text { Postop MRI: artifact of } \\
\text { flow across stoma; 1-yr } \\
\text { FU MRI: occl of ostium } \\
\text { w/ no flow artifact }\end{array}$ & $\begin{array}{l}\text { Reop to re- } \\
\text { move bone } \\
\text { frags }\end{array}$ & $\begin{array}{l}\text { Compl resol } \\
\text { of Sx }\end{array}$ & $\begin{array}{l}\text { Good CSF flow } \\
\text { in ostium; } \\
\text { stable imag- } \\
\text { ing findings } \\
\text { at 1-yr FU }\end{array}$ \\
\hline \multirow[t]{2}{*}{$\begin{array}{l}\text { Present } \\
\text { report }\end{array}$} & \multirow[t]{2}{*}{2} & Tectal glioma & $\begin{array}{l}\text { Endoscopy tract, } \\
\text { anterior 3rd } \\
\text { ventricle, } \\
\text { floor of It lat } \\
\text { ventricle }\end{array}$ & $\begin{array}{l}\text { Fever, neck pain } \\
\text { \& stiffness; } \\
\text { LP for aseptic } \\
\text { meningitis; } \\
3 \text { mos later: } \\
\text { progressive } \\
\text { HAs \& blurry } \\
\text { vision }\end{array}$ & $\begin{array}{l}\text { Postop CT: decr'd size of } \\
\text { 3rd \& 4th ventricles; } \\
\text { repeat CT: migr of bone } \\
\text { frags into endoscopy } \\
\text { tract \& 3rd ventricle; } \\
\text { 3-mo FU CT: enlarged } \\
\text { 3rd \& 4th ventricles w/ } \\
\text { stable bone frags }\end{array}$ & $\begin{array}{l}\text { Reop to } \\
\text { open new } \\
\text { ventricu- } \\
\text { lostomy } \\
\text { hole }\end{array}$ & $\begin{array}{l}\text { Resol of Sx } \\
\text { at FU }\end{array}$ & $\begin{array}{l}\text { Decr'd ventric } \\
\text { size \& good } \\
\text { flow across } \\
\text { 3rd ven- } \\
\text { triculostomy } \\
\text { defect at } \\
\text { 4-mo FU }\end{array}$ \\
\hline & & $\begin{array}{l}\text { Colloid cyst } \\
\text { in 3rd } \\
\text { ventricle }\end{array}$ & $\begin{array}{l}\text { Endoscopy tract, } \\
\text { lat ventricle }\end{array}$ & $\begin{array}{l}10 \text { wks postop: } \\
\text { HA, fever, } \\
\text { nausea \& } \\
\text { vomiting after } \\
\text { head trauma }\end{array}$ & $\begin{array}{l}\text { Follow-up CT: asymmet- } \\
\text { ric ventric dilation w/ } \\
\text { dystrophic calcification } \\
\text { along ventriculostomy } \\
\text { tract }\end{array}$ & $\begin{array}{l}\text { Reop to re- } \\
\text { move bone } \\
\text { frags \& } \\
\text { fenestrate } \\
\text { septum } \\
\text { pellucidum }\end{array}$ & $\begin{array}{l}\text { Resolution } \\
\text { of Sx at } \\
\text { FU }\end{array}$ & $\begin{array}{l}\text { Decr in size of } \\
\text { rt ventricle \& } \\
\text { near resol of } \\
\text { calcifications }\end{array}$ \\
\hline
\end{tabular}

Clin = clinical; compl = complete; $\mathrm{Cx}=$ change; decr = decrease; decr'd = decreased; frags = fragments; FU = follow-up; HA = headache; $\mathrm{HC}=$ hydrocephalus; $\mathrm{ICP}=$ intracranial pressure; incont = incontinence; infundib = infundibular; loc = location; $\mathrm{LP}=$ lumbar puncture; $\mathrm{MB}=$ mammillary body; $\mathrm{MF}=\mathrm{Monro}$ foramen; migr = migration; occip = occipital; occl = occlusion; path = pathological; progr = progression; radiogr = radiographic; regr = regression; resol = resolution; Sx = symptom $(\mathrm{s}) ;$ ventric = ventricular.

* Indication for endoscopic procedure

trauma. The patient required an endoscopic re-exploration with removal of the bone fragments in the endoscopy tract and fenestration of the septum pellucidum. Inspection of the ventricular system showed formation of an inflammatory membrane occluding the right ventricle outflow.

Two mechanisms of CSF flow obstruction are potentially caused by bone dust migration. First, a direct mechanical obstruction of natural CSF passages (e.g., foramen of Monro or fourth ventricle) by a large bone fragment, which was not seen in our 2 cases. Another mechanism could be an inflammatory response caused by scattered bone dust in the ventricles leading to the formation of an inflammatory membrane along the ventricular surface. This membrane can obstruct natural CSF flow pathways and previously created stomas (such as third ventriculostomy) and thus recurrence of hydrocephalus. In our reported cases, we believe that recurrent hydrocephalus was caused by scattered ventricular bone dust and inflammation. In 
addition to bone fragment migration, some reports have noted evidence of bone fragment revascularization and continued growth on follow-up imaging studies, adding the possibility of long-term complications. ${ }^{8,18}$ In 2 cases reported by Thomson et al. ${ }^{16}$ there was a delayed appearance of radiopacities in the endoscopy tract, with progressive enlargement of these radiopacities on subsequent scans in one of these 2 cases. Their third case included a pathological analysis of retrieved bone fragments that demonstrated viable fat cells; this was considered evidence that these bone fragments were growing masses. ${ }^{16}$ Similarly, in the case reported by Turhan and Ersahin,,$^{18}$ the extracted bone particles were noted to be tightly adhering to the ependymal lining, with significant bleeding upon their removal and clear vascular structures observed in the bone. While migration of small bone fragments into the ventricles might take a benign course in the short term, it appears that this viable bone can grow and potentially cause complications later in the clinical course. The authors reporting on potential bone growth recommended close radiographic and clinical follow-up for these patients, and possibly a preventive intervention.

As discussed before, the use of autologous bone fragments and dust for burr hole closure has caused complications in the above-discussed scenarios. It seems that bone fragment migration and its sequelae may be induced by external factors despite proper operative technique. Other than complete avoidance of this technique, one might consider modifications to minimize the chance of bone dust migration. One possibility would be to approximate the dura prior to the placement of bone fragments and dust. Another possibility would be to place a barrier, such as a layer of pericranium or dural substitute, in the epidural space between the dural closure and the bone graft to prevent bone fragments from migrating into the endoscopy tract or ventricles. Evidently, special patient and family counseling to avoid contact sports and head trauma, at least during the early postoperative period, may help prevent this and other complications that can result from external blows to the head. In patients who present with meningitis symptoms after surgery and require a lumbar puncture for CSF studies, perhaps a low-volume lumbar tap should be considered. However, whether this technique carries a lower risk of bone dust migration, as compared to large-volume taps, is unknown. In cases in which bone dust migration is discovered, it seems reasonable to observe the patients closely with routine imaging. However, patients who become acutely symptomatic will require urgent surgical intervention. Migrated bone fragments that are thought to be causing symptoms or a mechanical obstruction of the CSF pathways should be removed. We also recommend washing out scattered bone dust seen in the ventricles, if feasible. Bone dust can cause significant inflammation along the ventricular surface, which can result in closure of the created stoma and recurrence of symptoms (as seen in case 1).

\section{Conclusions}

The use of bone fragments and dust as an autologous graft for burr hole closure is not devoid of complications. The above-described cases demonstrate possible compli- cations of this common practice, some of which necessitated urgent surgical intervention. The benefits of using bone dust as a sealant for burr holes should be weighed against its potential complications. Our proposed modification to the technique involves approximating the dura prior to the placement of bone dust, or placing a physical barrier, such as a layer of pericranium or dural substitute, in the epidural space between the dural closure and the bone graft to prevent bone fragments from migrating into the endoscopy tract or ventricles. This modification of the technique was adopted at one of the 2 institutions to reduce the risk of bone dust migration, whereas the other institution abandoned the use of the technique.

\section{References}

1. Baidya NB, Berhouma M, Ammirati M: Endoscope-assisted retrosigmoid resection of a medium size vestibular schwannoma tumor model: a cadaveric study. Clin Neurol Neurosurg 119:35-38, 2014

2. Bouras T, Sgouros S: Complications of endoscopic third ventriculostomy. J Neurosurg Pediatr 7:643-649, 2011

3. Decq P, Schroeder HW, Fritsch M, Cappabianca P: A history of ventricular neuroendoscopy. World Neurosurg 79 (2 Suppl):S14.e1-S14.e6, 2013

4. Di Ieva A, Tam M, Tschabitscher M, Cusimano MD: A journey into the technical evolution of neuroendoscopy. World Neurosurg 82:e777-e789, 2014

5. Edwards RJ, Dirks PB: Gelfoam obstruction of endoscopic third ventriculostomy. Case illustration. J Neurosurg 105 (2 Suppl):154, 2006

6. El Damaty A, Marx S, Fleck S, Schroeder HW: Neuroendoscopic approach to intracranial ependymal cysts. World Neurosurg 97:383-389, 2017

7. Ho CL, Hwang PY: Endoscope-assisted transorbital keyhole surgical approach to ruptured supratentorial aneurysms. J Neurol Surg A Cent Eur Neurosurg 76:376-383, 2015

8. Kafadar A, Abuzayed B, Kucukyuruk B, Cetin E, Gazioglu $\mathrm{N}$ : Intracranial migration of bone dust after intraventricular neuroendoscopy complicating acute hydrocephalus and removal of bone dust: case report. Neurosurgery 67:E503E504, 2010

9. Kubota H, Sanada Y, Murakami S, Miyauchi M, Iwakura M, Nagatsuka K, et al: Long-term follow-up for ossification of autologous bone plug and skin sinking after periosteumpreserved burr hole surgery. Surg Neurol Int 8:204, 2017

10. Kulkarni AV, Riva-Cambrin J, Holubkov R, Browd SR, Cochrane DD, Drake JM, et al: Endoscopic third ventriculostomy in children: prospective, multicenter results from the Hydrocephalus Clinical Research Network. J Neurosurg Pediatr 18:423-429, 2016

11. Oppido PA, Fiorindi A, Benvenuti L, Cattani F, Cipri S, Gangemi M, et al: Neuroendoscopic biopsy of ventricular tumors: a multicentric experience. Neurosurg Focus 30(4):E2, 2011

12. Peris-Celda M, Da Roz L, Monroy-Sosa A, Morishita T, Rhoton AL Jr: Surgical anatomy of endoscope-assisted approaches to common aneurysm sites. Neurosurgery $\mathbf{1 0}$ (Suppl 1):121-144, 2014

13. Schulz M, Bührer C, Pohl-Schickinger A, Haberl H, Thomale UW: Neuroendoscopic lavage for the treatment of intraventricular hemorrhage and hydrocephalus in neonates. J Neurosurg Pediatr 13:626-635, 2014

14. Song JH, Kong DS, Shin HJ: Feasibility of neuroendoscopic biopsy of pediatric brain tumors. Childs Nerv Syst 26:15931598,2010

15. Tang CT, Baidya NB, Ammirati M: Endoscope-assisted neu- 
rovascular decompression of the trigeminal nerve: a cadaveric study. Neurosurg Rev 36:403-410, 2013

16. Thomson S, Tyagi AK, Chumas PD: Intracranial hypertrophic calcification complicating neuroendoscopy. Report of three cases. J Neurosurg 98:186-189, 2003

17. Tuchman A, Platt A, Winer J, Pham M, Giannotta S, Zada G: Endoscopic-assisted resection of intracranial epidermoid tumors. World Neurosurg 82:450-454, 2014

18. Turhan T, Ersahin Y: Intraventricular migration of the bone dust. Is a second operation for removal necessary? Case report and review of the literature. Childs Nerv Syst 27:719722,2011

\section{Disclosures}

The authors report no conflict of interest concerning the materi- als or methods used in this study or the findings specified in this paper.

\section{Author Contributions}

Conception and design: all authors. Acquisition of data: all authors. Analysis and interpretation of data: all authors. Drafting the article: all authors. Critically revising the article: all authors. Reviewed submitted version of manuscript: all authors. Administrative/technical/material support: Price, El Ahmadieh, Iskandar. Study supervision: Price, Weprin, Iskandar.

\section{Correspondence}

Angela V. Price: The University of Texas Southwestern, Dallas, TX. angela.price2@utsouthwestern.edu. 